American Journal of Agricultural and Biological Sciences 6 (1): 155-161, 2011

ISSN 1557-4989

(C) 2010 Science Publications

\title{
Corn Response to Nitrogen Timing and Rate under Strip Tillage and Low-Yield Environment in Southeastern Coastal Plains
}

\author{
${ }^{1}$ Pawel Wiatrak, ${ }^{2}$ Ahmad Khalilian and ${ }^{3}$ Guihua Chen \\ ${ }^{1}$ Department of Entomology, Soils and Plant Sciences, \\ ${ }^{2}$ Department of Biosystems Engineering, \\ Clemson University, Edisto Research and Education Center, Blackville, SC 29817 \\ ${ }^{3}$ Department of Land, Air and Water Resources, University of California, \\ Davis, 3140 Plant and Environmental Science Building, \\ One Shields Avenue, Davis, CA 95616
}

\begin{abstract}
Problem statement: Insufficient rainfall under low yield environment may affect nitrogen management, plant growth indices and grain yields of corn (Zea mays L.). Approach: The objective of this study was to determine the effects of two $\mathrm{N}$ application timings (all at planting and as split application with $\mathrm{N}$ applied at planting and V6 stage) and five $\mathrm{N}$ fertilizer rates $(0,45,90,135$ and 180 $\mathrm{kg} \mathrm{N} \mathrm{ha}^{-1}$ ) on strip-tilled, dryland corn growth and yields under low-yield environmental conditions near Blackville SC, from 2007-2009. Plant growth measurements included plant height, ear height, relative chlorophyll content (SPAD), Leaf Area Index (LAI) and normalized difference vegetation index (NDVI). Results: Plant LAI at V8, NDVI at V8 and R1, SPAD at R1, plant height at V8 and grain yield generally increased with increasing $\mathrm{N}$ application rates. Due to most likely insufficient precipitation, the $\mathrm{N}$ application timing did not affect corn growth or yield. Despite relatively low grain yields, corn yield was increased by $1.6 \mathrm{Mg} \mathrm{ha}^{-1}$ with increasing $\mathrm{N}$ application rate of $100 \mathrm{~kg} \mathrm{ha}^{-1}$. Grain yield was positively correlated with plant leaf area index (LAI) at R1 $(r=0.27, p \leq 0.05)$ and Normalized Difference Vegetation Index (NDVI) at V8 and R1 $(r=0.33$ and $0.29, p \leq 0.01$, respectively) and plant height at $\mathrm{V} 8$ stage $(\mathrm{r}=0.42, \mathrm{p} \leq 0.001)$. With $\mathrm{N}$ applied at planting, there was a 0.55 and $0.49 \mathrm{Mg} \mathrm{ha}^{-1}$ yield increase with 0.1 increases in plant NDVI at V8 and R1, respectively. Conclusion: Under strip tillage and low yield environment conditions, plant growth and yields may not be affected by timing of $\mathrm{N}$ application mainly due to insufficient rainfall. Plant NDVI (for treatments with all $\mathrm{N}$ applied at planting) at V8 and R1 can help to estimate potential of corn grain yield, which may be reduced due to low nitrogen use efficiency.
\end{abstract}

Key words: Corn growth, strip tillage, $\mathrm{N}$ application rate, nitrogen timing, Leaf Area Index (LAI), grain yield, Soil Plant Analysis Development (SPAD), chlorophyll meter, Normalized Difference Vegetation Index (NDVI), Electrical Conductivity (EC), low yield environment

\section{INTRODUCTION}

Plant $\mathrm{N}$ use efficiency can be improved by matching application rate and timing with plant demands (Ferguson et al., 2002). Russelle et al. (1983) showed that corn $\mathrm{N}$ uptake is affected by time of fertilizer application. Split application of $\mathrm{N}$ may help growers make better decision on $\mathrm{N}$ application (Feinerman et al., 1990), though sometimes producers are opting to apply $\mathrm{N}$ to corn in a single application due to increase fuel prices (Viswakumar et al., 2008). There are no general conclusions regarding the effect of split applications of $\mathrm{N}$ for various environmental conditions. Yield may increase using split application method when using irrigation (Randall et al., 2003; Gehl et al., 2005) or may not differ compared to one-time application under dryland conditions (Randall et al., 1997).

Remote sensing, a technology based on nondestructive light reflectance, has been used to estimate the crop $\mathrm{N}$ status in the field during the growing season (Osborne et al., 2002). The Normalized Difference Vegetation Index (NDVI) optical sensing technology measures the photosynthetic size of the crop canopy (Wiegand et al., 1991). Higher positive NDVI

Corresponding Author: P. Wiatrak, Department of Entomology, Soils and Plant Sciences, Clemson University, Edisto Research and Education Center, Blackville, SC 29817

Tel: 803-284-3343 ext. 261 Fax: 803-284-3684 
values indicate greater proportion of green vegetation and are associated with greater $\mathrm{N}$ uptake and hence higher yield (Raun et al., 2002; Moges et al., 2004). Additionally, chlorophyll (SPAD) meters have been used to measure chlorophyll in leaves. Although plant Leaf Area Index (LAI) meters have not been widely used due to difficulties of measuring LAI in the field, they can provide useful information on plant canopy status. However, plant LAI is influenced by nutrient deficiency. Jordan-Meille and Pellerin (2004) observed that corn had smaller LAI when potassium was deficient.

Tillage is one of the many factors influencing soil productivity (Licht and Al-Kaisi, 2005). In the southeastern U.S., strip tillage is the most common conservation tillage system. This system uses a seedbed preparation implement with in-row subsoil shanks, multiple coulters and ground-driven crumblers that till about $30 \mathrm{~cm}$ wide band (Johnson et al., 2001). However, conservation tillage systems present a challenge for integrating an efficient fertilizer program for corn production (Kwaw-Mensah and Al-Kaisi, 2006).

Relatively little research focuses on nitrogen utilization in low-yield environments. In the Southeastern Coastal Plain, corn is mostly grown under dryland conditions, where soils have low water and nutrient holding capacity and precipitation is unpredictable. Therefore, the objective of this study was to determine the effects of timing and rate of $\mathrm{N}$ application on corn growth and yield under dryland conditions with strip tillage in the Southeastern U.S.

\section{MATERIALS AND METHODS}

The study was initiated on Dothan loamy sand (fine loamy, kaolinitic, thermic Plinthic Kandiudult) at Clemson University, Edisto Research and Education Center near Blackville, SC, $\left(33^{\circ} 21^{\prime}\right.$ N, $81^{\circ} 19^{\prime}$ W) under dryland conditions in the fall of 2006. Electrical Conductivity (EC) of soil was measured using a Veris soil EC 3100 meter (Veris Technologies, Salina, KS). Trimble GPS (Trimble Sunnyvale, CA) was used to identify the variation of soil texture across the field. Experimental blocks were grouped by EC readings to minimize soil variation within blocks. At the initiation of this study, the average soil EC was 5.3 (based on Veris 3100 measurements) and soil $\mathrm{pH}$ was 6.2. The soil $\mathrm{K}, \mathrm{P}, \mathrm{Mg}, \mathrm{Ca}$ and organic matter content in the upper $15 \mathrm{~cm}$ were $59,29,88,325$ and $16 \mathrm{mg} \mathrm{kg}^{-1}$. Corn was planted in the summer prior to the experiment in 2006. Winter wheat (Triticum aestivum L.) cover crop was planted on 8 December 2006, 21 November 2007 and 26 November 2008 and killed by spraying glyphosate at a rate of $1.1 \mathrm{~kg}$ a.i. $\mathrm{ha}^{-1}$ on 26 February 2007 and 6 March in 2008 and 2009. The previous crop, prior to planting wheat cover crop, was corn. Daily precipitation and air temperature were recorded using an automated weather station located near the experimental site.

The experiment design was a split-plot arrangement in a randomized complete block with four blocks. The plot size was $3.9 \mathrm{~m}$ wide by $6.1 \mathrm{~m}$ long consisting of four corn rows. The treatments included two timings of $\mathrm{N}$ application (all at planting and as split application) and five $\mathrm{N}$ rates $(0,45,90,135$ and $180 \mathrm{~kg}$ $\mathrm{N} \mathrm{ha}^{-1}$ ). The split application included $35 \mathrm{~kg} \mathrm{~N}^{-1}$ applied at planting and the remaining $\mathrm{N}$ applied at $\mathrm{V} 6$ stage as sidedressing. A Univerferth Ripper-Stripper (Unverferth Mtg. Co., Inc., Falida, OH) implement was used to prepare seedbeds under strip-till in the spring prior to planting. Pioneer $31 \mathrm{G} 65$ corn (Pioneer Hi-Bred Intern. Inc., Johnston, IA), with a relative maturity of 119 days, was planted at 69,200 seeds $^{-1}$ in rows spaced $0.97 \mathrm{~m}$ apart using a John Deere 1700 MaxEmerge XP vacuum planter (John Deere Co., Moline, IL) on 14 March 2007 and a John Deere 7300 MaxEmerge II vacuum planter on 18 and 23 March in 2008 and 2009, respectively. Liquid fertilizer was surface applied in the form of urea-ammonium sulfate using a Reddick 4-row fertilizer applicator (Reddick Equip. Co., Inc., Williamson, NC) to selected plots following planting and as a sidedress $\mathrm{N}$ application. Weed control was based on the South Carolina Extension recommendations. Corn grain was harvested from the entire length of two center rows by hand on 29 and 30 August in 2007 and using an Almaco plot combine (Almaco, Nevada, IA) on 22 and 18 August in 2008 and 2009, respectively.

Plant Leaf Area Index (LAI), Normalized Difference Vegetation Index (NDVI), chlorophyll and height were measured from the two adjacent middle rows of each plot. Plant LAI and NDVI were measured within a 4-m segment of adjacent two rows and about 1 $\mathrm{m}$ above each row for NDVI at V8 and R1 corn growth stages using a LAI-2000 (Li-Cor, Lincoln, NE) and handheld GreenSeeker ${ }^{\mathrm{TM}}$ (NTech Industries, Inc. Ukiah, CA) instruments, respectively. Chlorophyll content was measured in the corn ear leaves between the base and leaf tip and halfway between leaf margin and midrib at R1 corn stage using a Minolta SPAD-520 meter (Konica Minolta Sensing, Inc., Japan). Plant height was measured to the tip of the whorl at V8 and tip of the tassel prior to harvest based on 10 randomly selected plants from each plot. Grain weight and moisture from hand-harvested plots was determined after shelling corn samples. All grain samples from the hand 
and combine harvested plots were tested for moisture using a Burrows Model 70 Digital Moisture Computer (Seedburo Equip. Co., Chicago, IL) and grain yield was converted to $155 \mathrm{~g} \mathrm{~kg}^{-1}$ moisture content.

The MIXED procedure of SAS (SAS V. 9.2, SAS Inst., Cary, NC) was used for all analyses. Application timing was the main plot and $\mathrm{N}$ rate was a split-plot. The MIXED procedure of SAS with the LSMEANS PDIFF option was used to compare the effects of application timing and $\mathrm{N}$ rate. Means were separated using PDIFF only when the tests were significant $(p \leq 0.05)$. Single degree-of-freedom contrasts were used to evaluate linear and quadratic effects of $\mathrm{N}$ rate on corn. When a contrast indicated that there was a significant $(p \leq 0.05)$ linear or quadratic response, a linear or quadratic regression model was fit using PROC REG (SAS V. 9.2, SAS Inst., Cary, NC). Pearson correlation coefficients (r) were calculated between corn grain yield and plant LAI, NDVI, SPAD and height using the CORR procedure of SAS.

\section{RESULTS}

Monthly mean temperature and total precipitation and average from the previous 20 year average are shown in Table 1. The mean air temperature during the corn growing season in each year was mostly similar to the 20 year average, except in March 2008 and 2009 when temperature was 3.4 and $3.6^{\circ} \mathrm{C}$ lower, respectively. Monthly and total precipitation in the growing season varied between years and influenced plant growth. Total precipitation was lower in 2007 and 2008, but greater in 2009. The greatest deficit of precipitation was recorded for March, May and August in 2007, June in 2008 and June and August in 2009. Excessive precipitation was observed in April and May, 2009.

Nitrogen application rate influenced plant LAI at V8 stage, NDVI at V8 and R1 stage and SPAD chlorophyll values at R1 stage.

Significantly higher plant LAI at V8 was recorded from treatments with applications of 45 and $90 \mathrm{~kg} \mathrm{~N} \mathrm{ha}^{-1}$ although there was no significant difference between 90 $\mathrm{kg} \mathrm{N} \mathrm{ha}{ }^{-1}$ and 0,135 and $180 \mathrm{~kg} \mathrm{~N} \mathrm{ha}^{-1}$ (Table 2). Nitrogen application did not affect plant LAI at R1 growth stage. Plant NDVI at V8 stage was smaller without $\mathrm{N}$ application compared to other application rates. Plant NDVI at $\mathrm{R} 1$ increased with $\mathrm{N}$ rate at a rate of 0.11 per $100 \mathrm{~kg} \mathrm{~N} \mathrm{ha}{ }^{-1}$ increase (Fig. 1). We observed a positive relationship between plant LAI and NDVI at both V8 and R1 stages (Fig. 2). For every one unit change in plant LAI, NDVI changed by 0.14 at V8 and 0.06 at R1. Further analyses showed that NDVI and LAI were strongly correlated at $\mathrm{V} 8$ and $\mathrm{R} 1(\mathrm{r}=0.56$, $\mathrm{p} \leq 0.001$ and $\mathrm{r}=0.54, \mathrm{p} \leq 0.001$, respectively). Relative chlorophyll content (SPAD) value at R1 was greater at the two highest $\mathrm{N}$ rates of 135 and $180 \mathrm{~kg} \mathrm{~N}^{-1}$ compared to other $\mathrm{N}$ rates (Table 2). A positive relationship was also observed between SPAD chlorophyll readings and plant NDVI (Fig. 3). Based on this relationship, when SPAD increased by 10 , plant NDVI increased by approximately 0.13 . Nitrogen application timing had no effect on any of the vegetation indices. Nitrogen application significantly influenced plant height at V8; however, not at either R1 or prior to harvest.

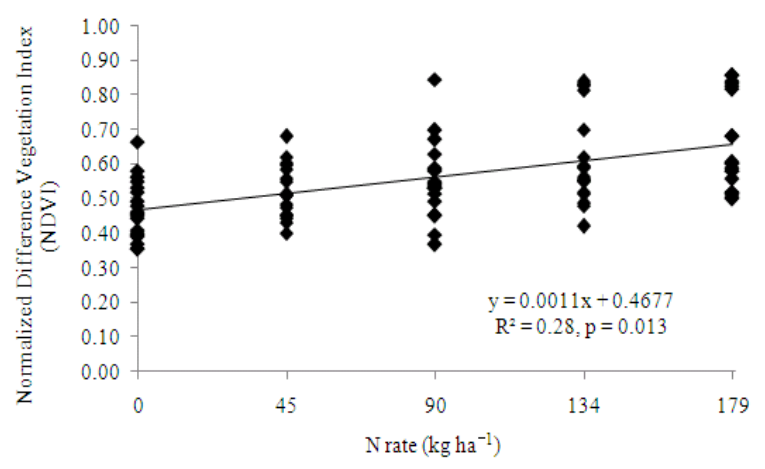

Fig. 1: Influence of $\mathrm{N}$ application rate on corn Normalized Difference Vegetation Index (NDVI) at R1 stage near Blackville SC, from 2007-2009

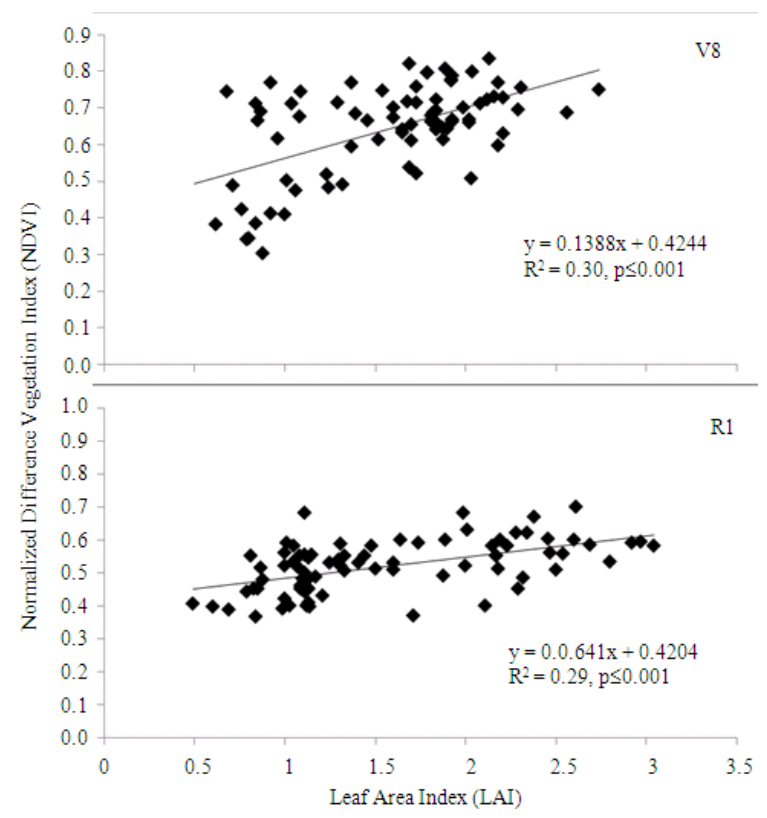

Fig. 2: Relationship between Leaf Area Index (LAI) and plant Normalized Difference Vegetation Index (NDVI) at V8 and R1 corn growth stages near Blackville SC, from 2007-2009 
Am. J. Agri. \& Biol. Sci., 6 (1): 155-161, 2011

Table 1. Monthly mean air temperature and total precipitation near Blackville SC, from 2007-2009

\begin{tabular}{|c|c|c|c|c|c|c|c|}
\hline \multirow[b]{2}{*}{ Year } & \multicolumn{7}{|l|}{ Month } \\
\hline & March & April & May & June & July & August & Average/Total \\
\hline \multicolumn{8}{|c|}{ Temperature, ${ }^{\circ} \mathrm{C}$} \\
\hline 2007 & 14.7 & 16.5 & 20.9 & 24.6 & 25.1 & 27.2 & 21.5 \\
\hline 2008 & 13.0 & 16.5 & 21.0 & 26.4 & 25.6 & 25.2 & 21.3 \\
\hline 2009 & 12.8 & 16.8 & 21.4 & 25.9 & 25.3 & 25.7 & 21.3 \\
\hline $20-y r$ avg. & 16.4 & 17.6 & 21.7 & 25.2 & 26.7 & 25.9 & 22.3 \\
\hline \multicolumn{8}{|c|}{ Precipitation, mm } \\
\hline $2007^{2}$ & 49.0 & 99.0 & 14.0 & 151.0 & 113.0 & 70.0 & 496.0 \\
\hline 2008 & 72.0 & 63.0 & 76.0 & 44.0 & 146.0 & 161.0 & 562.0 \\
\hline 2009 & 85.0 & 137.0 & 284.0 & 54.0 & 147.0 & 24.0 & 731.0 \\
\hline 20 -yr avg. & 106.0 & 80.0 & 88.0 & 129.0 & 130.0 & 123.0 & 653.0 \\
\hline
\end{tabular}

Table 2: Influence of $\mathrm{N}$ rate on plant vegetation indices (Leaf Area Index (LAI) and Normalized Difference Vegetation Index (NDVI)), relative chlorophyll content (SPAD) and plant height at V8 or R1 stage near Blackville SC, from 2007-2009

\begin{tabular}{lllll}
\hline $\begin{array}{l}\text { N rate } \\
\left(\mathrm{kg} \mathrm{N} \mathrm{ha}^{-1}\right)\end{array}$ & $\begin{array}{l}\text { LAI } 8 \\
0\end{array}$ & $\begin{array}{l}\text { NDVI } \\
\text { V8 }\end{array}$ & $\begin{array}{l}\text { SPAD } \\
\text { R1 }\end{array}$ & $\begin{array}{l}\text { Plant height }(\mathrm{cm}) \\
\text { V8 }\end{array}$ \\
\hline 05 & $1.38 \mathrm{~b} \dagger$ & $0.56 \mathrm{~b}$ & $36.1 \mathrm{c}$ & $128 \mathrm{c}$ \\
90 & $1.69 \mathrm{a}$ & $0.70 \mathrm{a}$ & $38.3 \mathrm{c}$ & $146 \mathrm{a}$ \\
134 & $1.48 \mathrm{ab}$ & $0.66 \mathrm{a}$ & $38.7 \mathrm{bc}$ & $142 \mathrm{ab}$ \\
179 & $1.30 \mathrm{~b}$ & $0.65 \mathrm{a}$ & $41.7 \mathrm{a}$ & $135 \mathrm{bc}$ \\
\hline & $0.66 \mathrm{a}$ & $41.7 \mathrm{ab}$ & $144 \mathrm{ab}$ \\
\hline
\end{tabular}
different at the 0.05 probability level

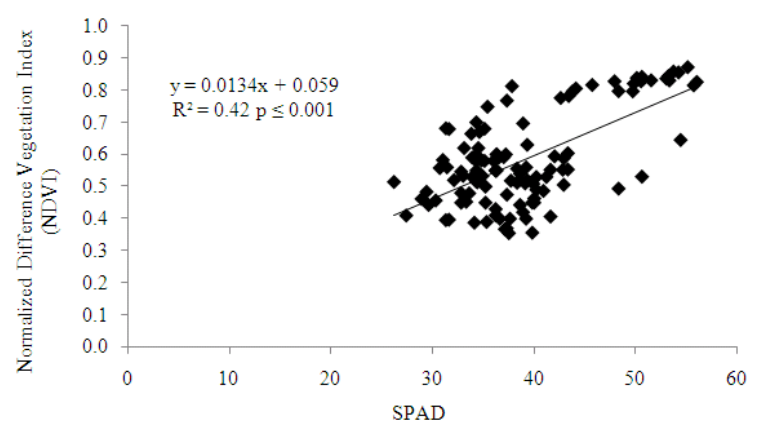

Fig. 3: Relationship between relative chlorophyll content (SPAD) and plant Normalized Difference Vegetation Index (NDVI) at R1 corn stage near Blackville SC, from 2007-2009

Plants at V8 were taller with application of 45, 90 and $180 \mathrm{~kg} \mathrm{~N} \mathrm{ha}{ }^{-1}$ compared to the control with no $\mathrm{N}$ application (Table 2). Plant NDVI at V8 was positively correlated with plant height at V8 corn stage (Fig. 4). When plant NDVI at V8 increased by 0.1 unit, plant height increased by about $18 \mathrm{~cm}$.

Corn yield increased by about $1.6 \mathrm{Mg} \mathrm{ha}^{-1}$ for every $100 \mathrm{~kg} \mathrm{~N} \mathrm{ha}^{-1}$ (Fig. 5). Grain yield was positively correlated with plant leaf area index (LAI) at R1 ( $\mathrm{r}=$ $0.27, \mathrm{p} \leq 0.05)$ and Normalized Difference Vegetation Index (NDVI) at V8 and R1 ( $\mathrm{r}=0.33$ and $0.29, \mathrm{p} \leq 0.01$, respectively) and plant height at V8 stage ( $\mathrm{r}=0.42$, $\mathrm{p} \leq 0.001)$. Also, a positive relationship was observed

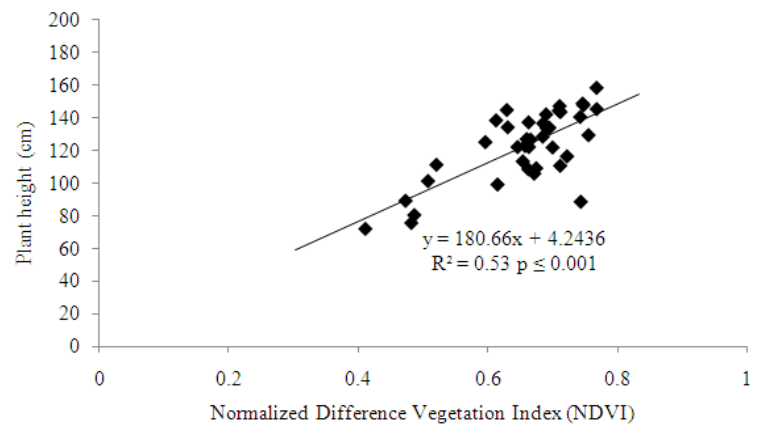

Fig. 4: Relationship between plant Normalized Difference Vegetation Index (NDVI) and plant height at V8 corn stage near Blackville SC, from 2007-2009 (data not collected for NDVI at V8 in 2007)

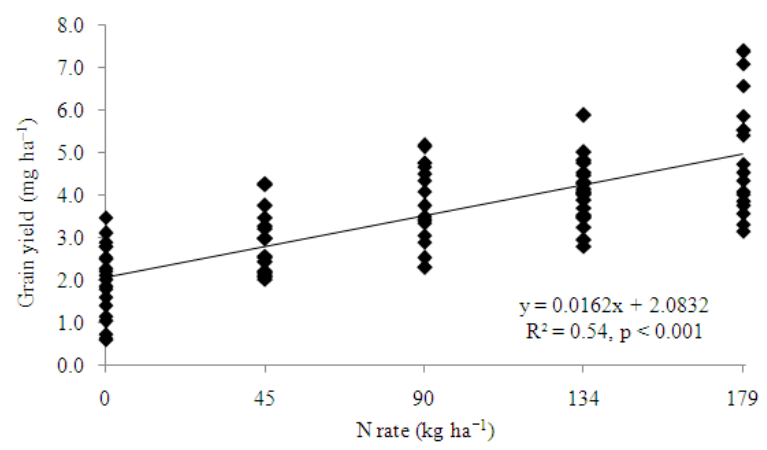

Fig. 5: Influence of $\mathrm{N}$ application on corn grain yield near Blackville SC, from 2007-2009

between grain yield and plant height at V8 (Fig. 6) and plant NDVI at V8 and R1 corn stages (Fig. 7). Corn grain yield increased by $0.35 \mathrm{Mg} \mathrm{ha}^{-1}$ with increasing plant height by $10 \mathrm{~cm}$. Also, we could expect approximately 0.55 and $0.50 \mathrm{Mg} \mathrm{ha}^{-1}$ yield increase with increasing plant NDVI by 0.1 at V8 and R1 corn stages, respectively. The timing of $\mathrm{N}$ application did not have an effect on grain yield. 


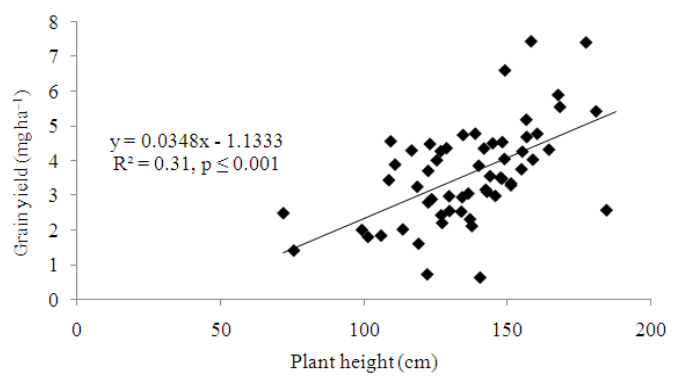

Fig. 6: Relationship between plant height at V8 stage and grain yield near Blackville SC, from 2007-2009

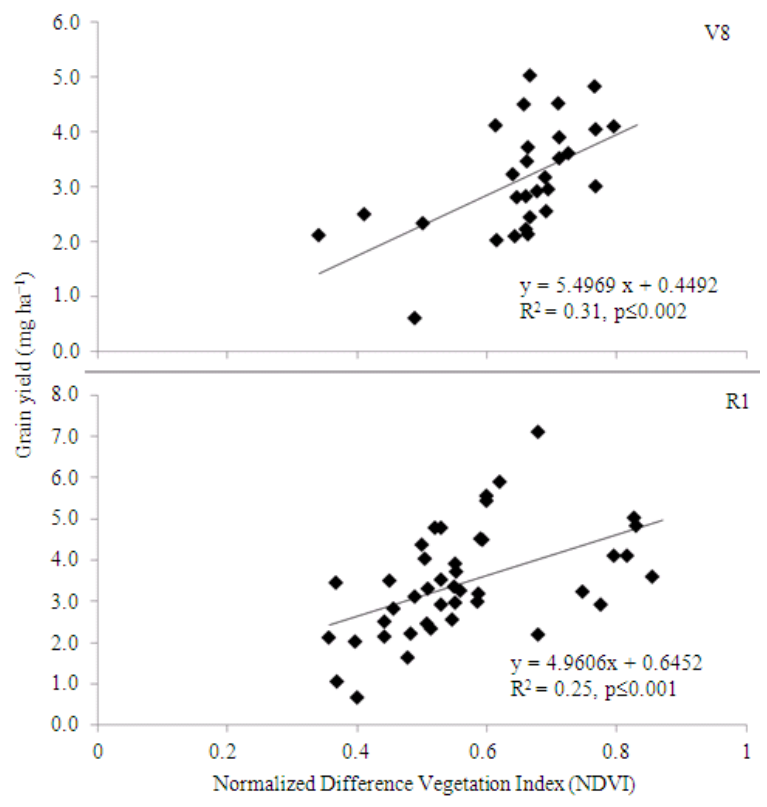

Fig. 7: Relationship between plant Normalized Difference Vegetation Index (NDVI) at V8 and $\mathrm{R} 1$ and grain yields with $\mathrm{N}$ applied at plant near Blackville SC, from 2007-2009 (data not collected for NDVI at V8 in 2007)

\section{DISCUSSION}

Plant NDVI at V8 and R1 increase with higher $\mathrm{N}$ was due to increased growth and/or greener plants, because NDVI reflectance in the NIR and red wavelengths is related to plant parameters like canopy cover and chlorophyll concentration (Shanahan et al., 2001). This could also explain the positive relationship between plant LAI and NDVI and SPAD chlorophyll and NDVI in our study. However, greater water deficit at R1 in 2 out of 3 years, due to insufficient precipitation might have impacted the effect of $\mathrm{N}$ rate on plant NDVI at V8 compared to R1. Russelle et al.
(1983) also noted that rate of $\mathrm{N}$ uptake is affected by variation of weather, planting time and time of $\mathrm{N}$ application and generally greatest uptake is from the eight leaf collar stage (V8) to silking (R1). Our study showed that timing of $\mathrm{N}$ application, either all $\mathrm{N}$ at planting or as split application, did not influence plant LAI and NDVI at either V8 or R1 stage or SPAD at R1. Strachan et al. (2002) indicated that corn growth is a function of $\mathrm{N}$ availability and water and midseason water deficits would override the effect of $\mathrm{N}$, if there were no other limiting factors present. In our study, low precipitation during V8 and R1 stages in 2 out of 3 yrs and especially water deficit at R1 in these yrs had the effect of $\mathrm{N}$ application on NDVI. Overall, plant NDVI increased at a relatively greater rate relative to $\mathrm{N}$ application rate at $\mathrm{R} 1$ than $\mathrm{V} 8$. This could be due to faster $\mathrm{N}$ uptake after V8 stage (Russelle et al., 1983). The results on plant height at V8 agree with Idikut et al. (2009), who reported that $\mathrm{N}$ fertilization increased plant height. In our study, increased plant height at V8 compared to $\mathrm{R} 1$ and prior to harvest could have been due to higher monthly rainfall during early growing season compared to June precipitation in 2 out of 3 year (Table 1). However, plant height, either at V8 and R1 stages or prior to harvest, was not influenced by timing of $\mathrm{N}$ application to corn most likely due to insufficient midseason rainfall.

Increase yields with $\mathrm{N}$ application agree with Idikut et al. (2009); however, the maximum yield in their study was obtained at $250 \mathrm{~kg} \mathrm{~N} \mathrm{ha}^{-1}$ when compared to treatments with 0 and $125 \mathrm{~kg} \mathrm{~N} \mathrm{ha}^{-1}$. A positive relationship between plant NDVI and grain yield agrees with Raun et al. (2001), who reported that grain yield of winter wheat determined from NDVI had a strong relation to actual grain yield. The effect of $\mathrm{N}$ application time on yield is not conclusive in the literature. Some researchers have reported that corn yield increased with split or sidedress $\mathrm{N}$ applications (Gehl et al., 2005; and Viswakumar et al., 2008), but others reported no yield difference between the two application methods in some years due to dry conditions throughout the growing season (Viswakumar et al., 2008), or reduced yield with split $\mathrm{N}$ applications (Randall et al., 1997). In our study, insufficient precipitation might be the reason for no yield difference between $\mathrm{N}$ applied at planting and through split applications. Due to most likely insufficient precipitation, overall relatively low grain yields were recorded, especially in 2008 and 2009 (3.1 and $2.8 \mathrm{Mg}$ $\mathrm{ha}^{-1}$, respectively), compared to 2007 (4.5 $\mathrm{Mg} \mathrm{ha}^{-1}$ ) when the precipitation in June was slightly above the 20 year average (Table 1). However, the most detrimental effect on corn yield may have been a drought period in 
June of 2008 and 2009 when corn was pollinating and most sensitive to water stress. This is in agreement with reports that mid-season water deficits would override the effect of N, even in a short duration (Strachan et al., 2002) and dry conditions during a growing season could result in low corn yield (Viswakumar et al., 2008; Haghighi et al., 2010), especially drought during silking period. Kim et al. (2008) also noted that the amount of $\mathrm{N}$ fertilizer needed to produce a unit of grain yield is related to the yield loss due to water stress. They observed higher $\mathrm{N}$ use efficiency in the high than moderate water regime. Generally, the results from our study indicated that corn grain yield mostly depended on plant height early in the season, which was affected by $\mathrm{N}$ utilization and also plant growth as shown using plant LAI and NDVI.

\section{CONCLUSION}

This study investigated the effects of timing and rate of $\mathrm{N}$ fertilizer application and rate on corn growth and yield in low-yield environment under waterstressed conditions. Plant LAI at V8, NDVI at V8 and $\mathrm{R} 1, \mathrm{SPAD}$ and plant height at V8 generally responded positively to $\mathrm{N}$ application rates. Also, grain yields were strongly affected by plant LAI at R1 and NDVI at $\mathrm{V} 8$ and R1 and height at V8. Under our low-yield environment, we could expect about $1.6 \mathrm{Mg} \mathrm{ha}^{-1}$ in grain yield increase with applying $100 \mathrm{~kg} \mathrm{~N} \mathrm{ha}^{-1}$ to corn. Measurements of plant NDVI at V8 and R1, for treatments with all $\mathrm{N}$ applied at planting, showed that grain yield increased by 0.55 and $0.50 \mathrm{Mg} \mathrm{ha}^{-1}$ with each increase in plant NDVI by 0.1 , respectively. Due to most likely irregular and especially insufficient rainfall, timing of $\mathrm{N}$ application did not affect corn growth or yields.

\section{ACKNOWLEDGEMENT}

We appreciate the support from International Plant Nutrition Institute (IPNI). This material is also based upon work supported by NIFA/USDA, under project number SC-1700328. Technical Contribution No. 5808 of the Clemson University Experiment Station.

\section{REFERENCES}

Feinerman, E., E.K. Choi and S.R. Johnson, 1990. Uncertainty and split nitrogen application in corn production. Am. J. Agric. Econ., 72: 975-984. DOI: $10.2307 / 1242629$

Ferguson, R.B., G.W. Hergert, J.S. Schepers, C.A. Gotway, J.E. Cahoon and T.A. Peterson, 2002. Site-specific nitrogen management of irrigated maize: Yield and soil residual nitrate effects. Soil Sci. Soc. Am. J., 66: 544-553.
Gehl, R. J., J.P. Schmidt, L.D. Maddux and W.B. Gordon, 2005. Corn yield response to nitrogen rate and timing in sandy irrigated soils. Agron. J., 97: 1230-1238. DOI: 10.2134/agronj2004.0303

Haghighi, B.J., Z. Yarmahmodi and O. Alizadeh, 2010. Evaluation the effects of biological fertilizer on physiological characteristic and yield and its components of corn (Zea mays L.) under drought stress. Am. J. Agric. Biol. Sci., 5: 189-193. DOI: 10.3844/ajabssp.2010.189.193

Idikut, L., I. Tiryaki, S. Tosun and H. Celep, 2009. Nitrogen rate and previous crop effects on some agronomic traits of two corn (Zea mays L.) cultivars Maverik and Bora. Afr. J. Biotechnol., 8: 4958-4963.

Johnson, W.C., T.B. Brenneman, S.H. Baker, A.W. Johnson and D.R. Sumner et al., 2001. Tillage and pest management considerations in a peanut-cotton rotation in the southeastern coastal plain. Agron. J., 93: 570-576.

Jordan-Meille, L. and S. Pellerin, 2004. Leaf area establishment of a maize (Zea mays L.) field crop under potassium deficiency. Plant Soil, 265: 75-92. DOI: $10.1007 / \mathrm{s} 11104-005-0695-\mathrm{z}$

Kim, K.I., D.E. Clay, C.G. Carlson, S.A. Clay and T. Trooien, 2008. Do synergistic relationships between nitrogen and water influence the ability of corn to use nitrogen derived from fertilizer and soil? Agron. J., 100: 551-556. DOI: 10.2134/agronj2007.0064

Kwaw-Mensah, D. and M. Al-Kaisi, 2006. Tillage and nitrogen source and rate effects on corn response in corn-soybean rotation. Agron. J., 98: 507-513. DOI: 10.2134/agronj2005.0177

Licht, M.A. and M. Al-Kaisi, 2005. Corn response, nitrogen uptake, and water use in strip-tillage compared with no-tillage and chisel plow. Agron. J., 97: 705-710. DOI: 10.2134/agronj2004.0102

Moges, S.M., W.R. Raun, R.W. Mullen, K.W. Freeman and G.V. Johnson et al., 2004. Evaluation of green, red, and near infrared bands for predicting winter wheat biomass, nitrogen uptake, and final grain yield. J. Plant Nutr., 27: 1431-1441. DOI: $10.1081 / \mathrm{pln}-200025858$

Osborne, S.L, J.S. Schepers, D.D. Francis and M.R. Schlemmer, 2002. Detection of phosphorus and nitrogen deficiencies in corn using spectral radiance measurements. Agron J., 94: 1215-1221.

Randall, G.W., J.A. Vetsch and J.R. Huffman, 2003. Corn production on a subsurface-drained Mollisol as affected by time of nitrogen application and nitrapyrin. Agron. J., 95: 1213-1219. 
Randall, G.W., T.K. Iragavarapu and B.R. Bock, 1997. Nitrogen application methods and timing for corn after soybean in a ridge-tillage system. J. Prod. Agric., 10: 300-307.

Raun, W.R., J.B. Soile, G.V. Johnson, M.L. Stone and E.V. Lukina et al., 2001. In-season prediction of potential grain yield in winter wheat using canopy reflectance. Agron. J., 93: 131-138.

Raun, W.R., J.B. Solie, G.V. Johnson, M.L. Stone and R.W. Mullen et al., 2002. Improving nitrogen use efficiency in cereal grain production with optical sensing and variable rate application. Agron. J., 94: 815-820.

Russelle, M.P., R.D. Hauck and R.A. Olson, 1983. Nitrogen accumulation rates of irrigated maize. Agron. J., 75: 593-598.
Shanahan, J.F., J.S. Schepers, D.D. Francis, G.E. Varvel and W.W. Wilhelm et al., 2001. Use of remote-sensing imagery to estimate corn grain yield. Agron. J., 93: 583-589.

Strachan, I.B., E. Pattey and J.B. Boisvert, 2002. Impact of nitrogen and environmental conditions on corn as detected by hyperspectral reflectance. Remote Sens. Environ., 80: 213-224. DOI: 10.1016/S0034-4257(01)00299-1

Viswakumar, A., R.W. Mullen, A. Sundermeier and C.E. Dygert, 2008. Tillage and nitrogen application methodology impacts on corn grain yield. J. Plant Nutr., $\quad 31$ : 1963-1974. 10.1080/01904160802403102

Wiegand, C.L., A.J. Richardson, D.E. Escobar and A.H. Gerbermann, 1991. Vegetation indices in crop assessments. Remote Sens. Environ., 35: 105-119. DOI: 10.1016/0034-4257(91)90004-P 